FENOMENA PEMAHAMAN DAN PENERAPAN HAKIKAT MAKNA KATA KEJAHATAN DAN PELANGGARAN DALAM PERKEMBANGAN HUKUM

Hamsir

$\mathrm{OO}$

IJTIHAD DAN URGENSINYA

Usman Jafar

$\longrightarrow 0$

PARTISIPASI POLITIK DALAM KONSEPSI TEORI PILIHAN RASIONAL JAMES S COLEMAN

Nila Sastrawati

THAHARAH LAHIR DAN BATIN DALAM AL-QURAN

(Penafsiran terhadap Qs. Al-Muddatsir/74:4 dan Qs. Al-Maidah/5:6)

Ahmad Mujahid, Haeriyyah

$-10$

STUDI KRITIS PERNIKAHAN BAWAH UMUR PERSPEKTIF UUP NO. 16 TAHUN 2019 DAN GENDER ANALISIS

Sippah Chotban

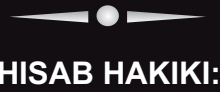

Metode IImiah Penentuan Awal Bulan Kamariyah

Alimuddin

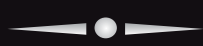

POLIGAMI DALAM SOROTAN

(Kajian Kitab-kitab Tafsir Modern/Kontemporer)

Halimah B

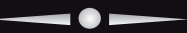

ADAT AMPIKALE:

Asuransi Ala Masyarakat Bugis di Kecamatan Pammana Kabupaten Wajo

Hadi Daeng Mapuna

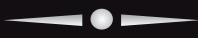

MEDIA SOSIAL DAN DAMPAKNYA TERHADAP PERCERAIAN

Sohrah

זע: HIMPUNAN ILMUWAN DAN SARJANA SYARIAH INDONESIA 


\section{$\underline{\text { Al-Risalah }}$}

Jurnal Ilmu Syariah dan Hukum

\section{DAFTAR ISI}

FENOMENA PEMAHAMAN DAN PENERAPAN HAKIKAT MAKNA KATA

KEJAHATAN DAN PELANGGARAN DALAM PERKEMBANGAN HUKUM

Hamsir

IJTIHAD DAN URGENSINYA

Usman Jafar

PARTISIPASI POLITIK DALAM KONSEPSI TEORI PILIHAN

RASIONAL JAMES S COLEMAN

Nila Sastrawati

THAHARAH LAHIR DAN BATIN DALAM AL-QURAN

(Penafsiran terhadap Qs. Al-Muddatsir/74:4 dan Qs. Al-Maidah/5:6)

Ahmad Mujahid, Haeriyyah

STUDI KRITIS PERNIKAHAN BAWAH UMUR PERSPEKTIF UUP NO. 16

TAHUN 2019 DAN GENDER ANALISIS

Sippah Chotban

HISAB HAKIKI: Metode Ilmiah Penentuan Awal Bulan Kamariyah

Alimuddin

POLIGAMI DALAM SOROTAN (Kajian Kitab-kitab Tafsir

Modern/Kontemporer)

Halimah B 
PERILAKU SEKSUAL TRANSGENDER

254-275

(Studi Komparatif Hak Asasi Manusia Antara Perspektif The Universal

Declaration of Human Right dan The Cairo Declaration of Human Right)

Adriana Mustafa

ADAT AMPIKALE: Asuransi Ala Masyarakat Bugis di Kecamatan Pammana

Kabupaten Wajo

276-285

Hadi Daeng Mapuna

MEDIA SOSIAL DAN DAMPAKNYA TERHADAP PERCERAIAN

286-296

Sohrah 


\title{
FENOMENA PEMAHAMAN DAN PENERAPAN HAKIKAT MAKNA KATA KEJAHATAN DAN PELANGGARAN DALAM PERKEMBANGAN HUKUM
}

\author{
Hamsir \\ Fakultas Syariah dan Hukum UIN Alauddin Makassar \\ hamsir91@gmail.com
}

\section{Abstract}

The word crime and violation in the legal phenomenon of society experiences distortion when reviewing sanctions from the act. The word crime means that sanctions are classified as severe, whereas violations are assumed to contain mild sanctions. In further legal developments, legal acts / legal events or offenses are identified with just one word, namely "criminal acts", both those charged with acts that are philosophically crimes or those philosophically charged with violations. By knowing the fundamental differences between the separation of crime and violation with a philosophical approach, the community will have a strong basis for applying the law (academic "theoretical" and "practical" and or for the compiler, "legislative law"). Acts, events, offenses or "Straafbaarfeit" crimes in straafrecht, sub-system of criminal offenses, and sub-criminal offenses. Therefore, uniting these two things into "criminal acts" only, contrary to the underlying thought and moral foundations. There are two factors that influence people's understanding of the nature of the meaning of the word crime and violation, namely: 1) Internal factors, the inability to interpret the meaning of the essence contained in these two things; 2). External factors, namely the existence of intentions to overturn the term for the sake of pragmatic interests and the inadvertence due to sources of information, news, literature, legislation that do not often mention and use these two terms in various legal events that occur in society.

Keywords: Actualization of Understanding Crimes and Violations

\section{A. PENDAHULUAN}

Masyarakat pada umumnya memaknai kejahatan dan pelanggaran dalam konteks yang sama, yang disebabkan antara lain adanya istilah hukum yang memiliki kemiripan, dan tidak dimaknai pada makna filosofi, sosiologis dan historis. Pada konteks hukum kejahatan dan pelanggaran baik dalam ucapan, maupun dalam penulisan pada hakikatnya berbeda.

Kata kejahatan dan pelanggaran, merupakan istilah yang ditemukan dalam sub judul kitab Undang-Undang Hukum Pidana (KUHP). Kecenderungan diberbagai produk perundang-unadangan khususnya produk legislatiff (DPR), ada kecenderungan tidak lagi mensistematisir akan atas kedua istilah tersebut, hal tersebut boleh jadi banyak pihak/orang keliru memahami kedua hal tersebut. Boleh jadi karena perkembangan pemahaman hukum mengalami perubahan. Misalnya dalam hukum tentang hak asasi manusia (UU HAM), Aktifitas negara/alat Negara yang membuat luka atau hilangnya nyawa 
(matinya orang), diketahui bila luka atau matinya seseorang yang dilakukan oleh orang lain secara individu atau sekelompok orang, maka orang/pelaku tersebut disebut penjahat, perbuatan disebut perbuatan jahat, kedua hal tersebut dinarasikan dengan bahasa tidak langsung dengan judul "kejahatan". Konsekwensi atas tindakan yang jahat tersebut, di berbagai buku, literature dan ungkapan kata dari berbagai pakar hukum, menyebut dengan pelanggaran atau pelanggaran HAM, bukan kejahatan HAM.

Terdapat kecenderungan tidak menempatkan istilah kejahatan pada konteks semestinya karena adanya ketakutan untuk mengatakan perbuatan itu adalah jahat, sehingga melemahkan kata perbuatan kejahatan dari suatu tindakan yang memang jahat, dan menggantinya dengan kata pelanggaran. Kata pelanggaran seolah-olah menghindari akan konsekwensi hukum yaitu sanksi atau hukuman badan berat yang akan diterima. Persoalan ini menjadi menarik, karena boleh jadi cara pandang rezim suatu negara dan individu warga negara terhadap, luka atau matinya (hilangnya nyawa) seseorang akaibat ulah negara disebut pelanggaran, bukan kejahatan.

Para ahli menyepakati perbuatan, tindakan, peristiwa atau delik kejahatan adalah perbuatan yang dirasakan langsung akibatnya oleh korban atau sasaran kajahatan tersebut (badan, jiwa/perasaans, seketika atau lama). Adapun perbuatan pelanggaran adalah perbuatan/tindakan/peristiwa yang tidak dirasakan langsung oleh korban (orang dan masyarakat, badan,jiwa/perasaan), namun efek perbuatan pelanggaran, dapat berkibat dikemudian hari terhadap orang/masyarakat, sehingga dapat isimpulkan bahwa, karakter kejahatan bersifat obyektif, karakter pelangaran bersifat subyektif.

Kata kejahatan dan pelanggaran, merupakan istilah yang ditemukan dalam sub judul kitab Undang-undang hukum pidana (KUHP), Disatu sisi bagi banyak pihak tidak menarik untuk dikomentari, namun bagi penulis dari pengalaman mengajar dihadapan mahasiswa, yang kelak mereka akan memberi pemahaman kepada pihak-pihak yang tidak memahami secara akademis, hakikat akan pengertian serta konsekwensi, penempatan kata tersebut atas suatu tindakan/peristiwa/perbuatan akan kejahatan tersebut, perlu diberi pemahaman yang mendalam akan hakikat arti kata kejahatan dan pelanggaran.

Diketahui diberbagai produk perundang-unadangan khususnya produk legislatiff (DPR), ada kecenderungan tidak lagi mensistematisir akan atas kedua istilah tersebut, hal tersebut boleh jadi banyak pihak/orang keliru memahami kedua hal tersebut. Boleh jadi karena perkembangan pemahaman hukum mengalami perubahan. Misalnya dalam hukum tentang hak asasi manusia (UU HAM), Aktifitas negara/alat Negara yang membuat luka atau hilangnya nyawa (matinya orang), diketahui bila luka atau matinya seseorang yang dilakukan oleh orang lain secara individu atau sekelompok orang, maka orang/pelaku tersebut disebut penjahat, perbuatan disebut perbuatan jahat, kedua hal tersebut dinarasikan dengan bahasa tidak langsung dengan judul "kejahatan". Konsekwensi atas tindakan yang jahat tersebut, di berbagai buku, literature dan 
ungkapan kata dari berbagai pakar hukum, menyebut dengan pelanggaran atau pelanggaran HAM, bukan kejahatan HAM.

Terdapat kecenderungan masyarakat secara tidak langsung melemahkan makna kejahatan dari suatu tindakan yang memang jahat, melalui penggunaan kata pelanggaran. Penggunaan kata tersebut seolah-olah menghindari akan konsekwensi hukum yaitu sanksi atau hukuman badan berat yang akan diterima. Persoalan ini menjadi menarik, karena boleh jadi cara pandang tersebut berkonsekuansi pada pembiaran kejahatan apalagi jika menyangkut hilangnya nyawa seseorang.

Terkait dengan hal tersebut, dalam penulisan ini mengkaji; pertama, bagaimana ketentuan hukum dan perundang-undang terhadap kata dan makna kejahatan dan pelanggaran dalam istilah hukum dan perundangundangan pidana. Kedua, bagaimanakah implementasi istilah kejahatan dan pelanggaran dalam praktik. Penulisan ini bertujuan menganalisis ketentuan hukum terhadap istilah kejahatan dan pelanggaran dalam istilah hukum dan perundang-undangan pidana serta aplikasinya dalam masyarakat.

\section{B. PEMBAHASAN}

Pada masyarakat terdapat perbedaan dalam menyikapi makna kata kejahatan dan pelanggaran dan mengarah kepada adanya kekeliruan dalam memahami arti, makna dan hakikat perbuatan kejahatan dan pelanggaran. Adapun masyarakat yang dimaksud disini, ada dalam tiga lapisan yakni; a) kalangan The man on the street (awam). b) lapis kedua kalangan the student (pelajar). c) kalangan the yuristen (ahli/mahasiswa hukum). ${ }^{1}$

Makna kejahatan seringkali dimaknai sama dengan pelanggaran oleh masyarakat. Hal ini antara lain, secara kesejarahan bentuk hukum tertulis yang ada di adopsi dari Belanda, sehingga memungkinkan untuk diterjemahkan lebih jauh, bahkan dimaknai, ditafsirkan, diinterpretasikan. Namun karakter tertulis atau sistem tertulis sebagai corak hukum pidana dan tidak menghendaki bentuk penganalogian, namun disatu sisi perkembangan masyarakat yang melakukan perbuatan kejahatan dan pelanggaran yang semakin canggih "sophistiscated" sehingga sulit terkualifaikasi sebagai delik selama para ahli hukum tidak berani pula menafsirkan hukum-hukum tertulis yang ada.

Pada Pasal 1 (ayat 1), KUHP dikemukakan bahwa tidak ada suatu perbuatan dapat dipidana/dihukum bila perbuatan tersebut tidak ada atau tiada disebut dalam suatu perundang-undangan pidana" (Nullum delictum nulla sine praevia lege). Terkait hal pemaknaan kejahatan dan pelanggaran secara tepat, dapat dilakukan melalui analisis pada berbagai aspek.

\section{Kejahatan dan Pelanggaran dalam Perspektif Hukum Pidana, Tata Negara dan Konstitusi}

Kaitan akibat bentuk tertulis pidana yang teksnya harus tertuang dalam

${ }^{1}$ Apeldoorn, Inleiding tot de studie van het nederlandse recht, terj Pelajaran Ilmu Hukum di Perguruan Tinggi (Sinar Baru, Bandung,1984)h. 1-9 
undang-undang, diartikan bahwa bila perbuatan tersebut dilawan, diterobos, diabaikan, dilakukan atau diikuti oleh seseorang, maka orang tersebut telah langgar/melanggar. Artinya perbuatan orang tersebut bertentangan dengan keinginan/kemauan/kehendak isi teks pasal undang-undang tersebut, meskipun itu prihal buku 2 dan undang-undang lainnya yang terkait kejahatan terkait pasal-pasal perbuatan kejahatan disebut juga ada pelanggaran. Pada hal kata melangggar lebih tepat dalam buku 3 dan undang-undang lainnya tentang di luar kejahatan, misalnya pelanggaran dalam undang lalu lintas dan jalan raya (UU LLAJR). Arti kata langgar tersebut menjadi satu-satunya istilah dalam dua perilaku (permanent/tetap dan yang inmanent/tidak tetap).

Hal ini menunjukkan tidak dapat seseorang sesudah berbuat atau tidak memenuhi perintah negara untuk membayar pajak kendaran, lalu kemudian dikatakan telah berbuat kejahatan dan harus diberi sanksi atas kejahatannya. Tepatnya adalah bila melanggar seperti yang perintah negara yang tertulis dalam undang-undang (sifat subyektif negara), maka sanksinya denda yang lebih ringan dari sanksi perbuatan kejahatan. Hal ini berbeda bila perintah kepemilikan SIM diabaikan seseorang, maka pengabaiannya dapat dikualifikasi "kejahatan". Demikian juga bila seseorang telah telah menghilangkan nyawa seseorang/membunuh, melukai, menyakiti seseorang baik pisik atau psikhis "perasaan hati", lalu/dapat dikatakan orang tersebut telah melakukan perbuatan jahat, tepatnya adalah menjahati/kejahatan terhadap diri seseorang yang aturannya tertulis dalam undang-undang (sifat obyektif warga negara dan negara).

Hakikat membedakan perbuatan/peristiwa/tindakan/delik kejahatan dan pelanggaran, oleh Jonkers dalam buku Zainal Abidin Farid, bahwa perihal "kejahatan" dikatergorikan sebagai "rechtsdelicten", perbuatan yang sangat tidak adil menurut filsafati, yaitu tidak bergantung pada ketentuan pidana yang ada,tetapi ada dan dirasakan dalam kesadaran diri manusia, berupa kesadaran batin manusia bahwa perbuatan itu adalah adalah perbuatan batil, tidak sah yang ditentukan oleh undang-undang. Lebih jelasnya Zainal Farid Abidin, bahwa delik adalah perbuatan tercela oleh masyarakat dan pembuatnya patut diberi sanksi pidana, tanpa memperhatikan ketentuan pidana yang ada. Artinya jahatnya perbuatan itu itu karena penilaian masyarakat lalu ditetapkan oleh undang-undang sebagai kejahatan. ${ }^{2}$

Kata Kejahatan pada Kamus Hukum, yakni suatu tindak pidana yang tergolong berat, lebih berat dari sekedar pelanggaran; perbuatan yang sangat anti sosial, yang oleh negara dengan sadar menjatuhkan hukuman kepada pelakunya; perbuatan jahat; sifat yang jahat. ${ }^{3}$ Kata pelanggaran adalah wetsdelicten, atau suatu perbuatan tidak tercela bukan perbuatan kejahatan, namun pelaku/pembuatnya patut dihukum/dipidana dan ditetapkan oleh Negara/pembuat undang-undang sebagai delik dalam kerangka kepentingan

\footnotetext{
${ }^{2}$ Zainal Abidin Farid, Hukum Pidana I(Sinar Grafika, Jakarta,2014) h. 352.

${ }^{3}$ Soesilo Prajogo, Kamus Hukum Internasional dan Indonesia (wacana intelektual,Jakarta, 2007), h. 244
} 
menjaga dan mempertahankan ketertiban, keamanan umum, dan ketertiban umum yang gilirannya menjaga kemaslahatan dan kesejahteraan dan kesehatan umum. ${ }^{4}$ Kata pelanggaran dalam kamus hukum, yatu: Suatu jenis tindak pidana tetapi ancaman hukumannya lebih ringan dari pada kejahatan, baik yang berupa pelanggaran jabatan atau pelanggaran undang-undang (KUHP pasal 489$).{ }^{5}$

Pentingnya memahami perbedaan kejahatan dan pelanggaran, ditelusuri Eddy O.S. Hiariej dengan mengutip bukunya Piers Baire dan James Messerschmidt, bahwa tindak pidana atau legal definition of crime itu dibedakan mala in se yakni suatu kejahatan berupa perbuatan yang sejak awal dirasakan "sejak manusia pertama kali ada", sebagai suatu ketidak adilan karena bertentangan dengan kaidah-kaidah dalam masyarakat sebelum ditetapkan dalam undang-undang, sedang mala prohibita.diidentikkan dengan pelanggaran, yakni perbuatan-perbuatan yang lebih dahulu ditetapkan dalam undang-undang, baru dinyatakan hukum. ${ }^{6}$

Kaitan substansi kejahatan dan pelanggaran, dalam perkembangan pemahaman orang atau para ahli hukum, dalam hal ini dikaitkan dengan salah satu peristiwa dan undang-undang yang ada, dalam pendekatan delik pelaporan/pengaduannya antara lain UU no. 19 tahun 2016 tentang Informasi dan Transaksi Elektronik (ITE). Dalam kaitan tulisan ini dicoba untuk dikaitkan kasus awal nopember 2019, yang dilaporkan oleh seseorang, terhadap seseorang. Kasus seseorang disangkakan pasl 32 ayat 1 jo Pasal 48 ayat 1 UU ITE no.19/2016).

Memahami kehadiran UU no.19/2016 tentang ITE, sebagai suatu perbuatan yang mengenai seseorang, dan seseorang tersebut berhak untuk melaporkan/mengadukan (delik aduan) kepada pelakunya sebagai perbuatan yang tidak menyenangkan. Kata tidak menyenangkan sesungguhnya sasaran orang/objek yang dikenai merasa telah dijahati oleh seseorang, olehnya ia harus mengadu ke meja hukum/pengadilan sebagai delik kejahatan.

Undang-undang tersebut meisyaratkan delik formil yang mengadukan adalah yang teraduh, terjahati, bukan orang lain atau yang bersangkutan sendiri. Timbul pertanyaan apakah yang bersangkutan yang terjahati tersebutlah yang melaporkan sebagai aduan, pada hakikatnya boleh orang lain, misalnya kerabat "lawyers", teman, keluarga atau yang bersimpati, sepanjang korban tersebut tidak melarangnya. Karena perbuatan jahat yang tersakiti/terjahati (luka atau hilang nyawa) tidak akan mungkin dapat berjalan "korban kondisi tidak stabil fisik atau non fisik", sangat sulit berbuat menemui prosedur hukum (due process of law). Misalnya perbuatan Bullying membuat seseorang perasaan " hatinya terjahati" dari perbuatan ucapan, kata dan gambar dari suatu media (kertas atau elektronik).

\footnotetext{
${ }^{4}$ Zainal Abidin Farid, Hukum Pidana I, h. 352.

${ }^{5}$ Soesilo Prajogo, Kamus Hukum Internasional dan Indonesia, h. 244.

${ }^{6}$ Eddy O.S. Hiariej, Prinsip-Prinsip Hukum Pidana (Cahaya Atma Pustaka, Yokyakarta, 2014). h, 101-102.
} 
Tindak pidana kejahatan dan pelanggaran dalam perspektif hukum pidana, lebih banyak memakai kata "Delict" (Inggris) yakni, "serangkaian tindakan, perbuatan, perbuatan yang unsur-unsur telah memenuhi rumusan yang ada rumusan pasal perundang-undangan pidana yang ada7, yakni perbuatan yang dianggap melanggar undang-undang atau dimana sipelanggarnya dapat dikenakan hukuman pidana atas perbuatan tersebut; perbuatan tersebut dinamakan tindak pidana atau kejahatan pidana. ${ }^{8}$

Dapat disimpulkan, kecenderungan beberapa pihak pemerhati hukum pidana, memandang pembagian kejahatan dan pelanggaran masih relevan berdasarkan hakikat kaulifikasi, hakikat klasifikasi dan hakikat kategori delik. Olehnya, perlu pemerintah senantiasa memperhatikan, mendengar dan mengamati para pakar dan atau pemerhati hukum pidana pengaturan perbuatan kejahatan dan perbuatan pelanggaran, merupakan tanggung jawab negara melalui alat-alat negara, baik sebagai obyek maupun subyek sasaran untuk menjadikan masyarakat menjadi tertib, aman dan sejahtera melalui aspek hukum.

Pada perspektif konstitusi dan ketatanegaraan, hal yang menjadi perbedaan pandangan dikalangan masyarakat dalam menyikapi produk perundangan-undangan yang dipandang mengandung unsur pelanggaran pada tataran implementasi aturan. Terkait hal tersebut, dibutuhkan peran penyusun produk undang-undang (legislatif) dan pelibatan ahli hukum sehingga produk perundang-undangan tersebut memiliki kesesuaian antara teori dan implementasinya. Hal lain, dengan eksistensi presiden (eksekutif) sebagai pemerintah yang didukung atau mayoritas koalisi dengan DPR (legislative), maka akan melahirkan kekuatan politis dukungan, yang membuka ruang untuk tawar menawar posisi jabatan kekuasaan "bargaining position". 9

Di Indonesia secara teori, "pemisahan kekuasaan" secara ketat, tidak dapat terwujud, maka dilahirkan teori "pembagian kekuasaan", yang tentunya berbeda dengan "pemisahan". Dalam pembagian kekuasaan dominasi praktek politik yang kuat yang cenderung hukum hanya digunakan sebagai alat pelengkap untuk memperkuat, bukan hukum sebagai tujuan yang berdiri sendiri atau mempunyai kekuatan mandiri "kemandirian hukum"

\section{Kejahatan dan Pelanggaran dalam Perspektif Hak Asasi Manusia (HAM)}

Kejahatan dan pelanggaran secara substansi mengenai suatu perbuatan, peristiwa, tindak dan delik dalam perspektif HAM dan di luar perspektif HAM, mempunyai perbedaan. Hal tesebut dapat dibaca dan diamati dalam bunyi Pasal 4 Undang Undang No.26 Tahun 2000 Pengadilan HAM bertugas dan berwenang memeriksa dan memutus perkara "pelanggaran" HAM yang berat. Kata Pelanggaran HAM berat yang dimaksud sebagaimana ketentuan Pasal 7

7 Zainal Abidin Farid, Hukum Pidana 1 (Remaja Rosdakarya, Jakarta, 2007), h, 220-224.

${ }^{8}$ Soesilo prajogo, Kamus Hukum, Internasional, Indonesia (Wacana Intelektual,Jakarta, 2007)h. 120.

9 Diskusi Hukum TV One, Reflleksi Kemandirian Hukum, Politik dan Kekuasaan dalam Negara Demokrasi, Desember 2017. 
Undang Undang No.26 Tahun 2000 yakni; kejahatan Genosida, dan kejahatan terhadap kemanusiaan.

Kata pelanggaran dalam Undang Undang tersebut memuat suatu perbuatan, peristiwa atau tindak kejahatan. Rumusan perbuatan kejahatan genosida yang dimaksud, yakni suatu perbuatan yang dilakukan dengan maksud dan tujuan untuk menghancurkan, memusnahkan "membuat orang hilang nyawa", seluruh atau sebagian kelompok bangsa, ras, etnis atau suatu agama. Sedangkan dimaksud "kejahatan" kemanusiaan, adalah suatu perbuataan yang dilakukan sebagai bagian dari serangan yang meluas atau sistematik dan serangan tersebut ditujukan secara langsung terhadap penduduk sipil, antara lain; pembunuhan, pemusnahan, perbudakan, pengusiran atau pemindahan penduduk secara paksa, perampasan kemerdekaan atau perampasan kebebasan secara fisik lain secara sewenangwenang yang melanggar asas ketentuan pokok hukum internasional, penyiksaan, perkosaan, perbudakan seksual, pelacuran secara paksa, pemaksaaan kehamilan, pemandulan atau ste., rilisasi secara paksa atau bentuk-bentuk kekerasan seksual yang setara. Penganiayaan terhadap suatu kelompok tertentu atau perkumpulan yang disadari persamaan pahan politik, ras, kebamgsaan,nis, budaya , agama, jenis kelamin atau alas an lain yang diakui secara universal sebagai hal yang dilarang menurut hukum internasional, penghilangan orang secara paksa, dan kejahatan apartheid

Secara universal substansi dan istilah "kejahatan dan pelanggaran" dalam perundang-undangan HAM, dapat kita temui suatu perbedaan dalam pengungkapan kata "kejahatan dan pelanggaran" dalam pengaturan pada Kitab Undang Undang Hukum Pidana (KUUHP). Hakikat suatu perbuatan kejahatan diatur tersendiri dalam bab/ buku 2 dan Hakikat suatu pelanggaran diatur dalam bab/buku 1. Nampaknya ada ketegasan pengertian hakikat dan filosofi perbuatan kejahatan dan pelanggaran.

Dalam perundang-undangan HAM sebagai hukum yang mengatur tentang sanksi, pembuat dan perbuatannya disebut, maka semua anasir-anasir pelaku, perbuatan dan sanksi disebut perbuatan pelanggaran (pelanggaran HAM)n atau terkadang dibagi menjadi 2 bagian yakni, pelanggaran HAM ringan dan pelanggaran HAM berat. Pelanggaran HAM yang dimaksud tersebut, dalam teori dan prakteknya adalah kejahatan, sehingga rumusan deliknya disebut kejahatan. Pemahaman istilah dan terkait substansi pelaku pelangggar HAM, memerlukan cara pemahaman tersendiri dalam kerangka membedakan istilah dan substansi "kejahatan dan pelanggaran" yang terdapat dalam Kitab undang-undang Hukum Pidana (KUUHP).

Disimpulkan bahwa, pengertian dan pemahaman istilah dan substansi "kejahatan dan pelanggaran", dalam KUUHPidana, secara substantive filosofis dapat dipahami, dalam perundang-undangan HAM khususnya dalam Undang-undang peradilan HAM, secara teks tidak ada pemisahan pengertian kedua hal tersebut, cenderung menyamakan kedua istilah tersebut dalam istilah dan praktek. 


\section{Kejahatan dan Pelanggaran dalam Perspektif Perkembangan Hukum}

Pada naskah rancangan Kitab Undang Hukum Pidana (RUU KUUHPidana), terlihat sangat jelas dalam sistematika pembukuannya pada sub-sub pada daftar isi, ketentuan tentang kejahatan misdrijven dalam buku 2 dan ketentuan tentang Pelangaran overtredingen dalam buku 3 KUUHpidana, tidak lagi tersusun seperti itu. Artnya dalam RUUKUHPidana, kedua ketentuan dalam sistematika sub bab 2 dan 3,dijadikan sub tersendiri menjadi satu sub bab saja, yaitu sub tentang ketentuan Tindak Pidana buku 2 dan buku 1 tentang ketentuan umum, sehingga ketentuan tentang pelanggaran dihapus dan materinya ditampung dalam kualifikasi tindak pidana buku 2.

Beberapa alasan penghapusan kata kejahatan dan pelanggaran, dalam perkembangannya, tidak adanya konsistensi tentang rumusan unsur-unsur perbutannya dan sanksinya, sehingga hakikat dan makna dari perbuatan rechtsdelict (kejahatan) dikualifikasikan atau terkulifikasi dalam wetsdwlicht (pelanggaran). Nampak beberapa aturan perundang-undangan menggunakan kata pelanggaran berat dengan konsekwensi sanksi yang diperberat, begitupun sebaliknya. Namun yang nampak adalah sepatutnya rumusan perbuatan tersebut adalah perbuatan kategori kejahatan dengan sanksi yang berat pula,

Nampaknya kata kejahatan dan pelanggaran, khususnya kata kejahatan, semakin jarang digunakan, boleh jadi ada "upaya terselubung" pengkaburan, bahkan upaya itu nampak dalam RUU KUHP thn 2002, kejahatan dn pelanggaran terkulifikasi dalam ketentuan 2 buku, yakni buku 1 ketentuan umum, buku 2 tentang ketentuan Tindak Pidana.

\section{Persfektif Fenomena Materialisme dan Fenomena Pragmatisme}

Hukum tidak hidup sendiri dalam masyarakat, dalam upaya kemandiriannya senantiasa dipengaruhi oleh beberapa aspek kehidupan yang mengitarinya, aspek budaya, ekonomi, politik dan dibarengi perkembangan teknologinya "IT". Tentunya begitupun sebaliknya, bila hukum yang baik dapat pula mempengaruhi kehidupan sosial, budaya dan ekonomi masyarakat. seperti yang pernah dikemukakan, "the law of Tool sosial engineering" Roscow Pound.

Dalam kaitan dominasi sosial, ekonomi, politik dan budaya dalam Negara, dapat mempengaruhi hukum atau, dari hukum yang dalam arti "substansial" menjadi hukum yang "tehnikial" semata. Hal tersebut terjadi, dengan eforia kehidupan sosial dan ekonomi yang kecenderungan materialistis dan dibarengi system kekuatan politik yang dominan dalam rangka mengejar dan memperkuat kekuasaan, maka hukum akan terlupakan atas eforia ekonomi yang mengejar bergerak cepat, seolah-olah bahwa, perubahan pada kekuatan ekonomi dan penguatan politik, maka bangsa dan masyarakat akan maju "peradaban".

Kondisi keadaan ini, melahirkan sifat, pragmatism "ingin segera cepat, mengabaikan, menyeragamkan tujuan substansial menjadi sekedar teknis" karena kecenderungan manusia untuk bergerak cepat dan tepat, sehingga sebagian besar masyarakat dalam gerak cepat tersebut tidak menjadi benar, 
bahkan menerabas dengan berbagai cara "menghalalkan cara". Gerakan cepat yang tidak tepat,tidak benar tersebut terkadang disadari bahwa hal tersebut bertentagan dengan nurani, jiwa dan kaidah-kaidah berkehidupan yang baik, dengan lahirnya mental-mental cepat dengan melompati hal yang tidak patut dilompati, cepat tiba cepat selesai, mengabaikan, meniadakan, menyeragamkan substansi ke teknis dan atau mengurangi proses yang harus ada, pada hal dalam proses itu, ada makna ada filosofi yang kelak sebagai modal dan benteng moral.

Palam perkembangan hukum, keberadaan undang-undang lalu lintas dan jalan raya bahwa kecepatan kendaraan di jalanan nasional/propinsi dan daerah dengan standar kecepatan maksimal 20 dan $40 \mathrm{~km}$ perjam. Namun hal tersebut sulit terwujud, akibat faktor kecepatan berbagai kendaraan kecepatan di atas standar $40 \mathrm{~km}$ perjam (50 - $60 \mathrm{~km}$ perjam) sebagai satuan standar kecepatan, kecuali di atas jalan tol. Informasi media10, bahwa awal-awal tahun 90- an sampai saat ini tahun 2000- an, bahwa dominan hilangnya/melayangnya nyawa seketika berasal dari jalan raya sebagai pembunuh nomor satu saat ini.

\section{Perspektif Masyarakat dan Pemerintah dalam Mengkualifikasikan Kata Kejahatan dan Pelanggaran}

Kata kejahatan bermula dari perbuatan yang dianggap tidak sesuai kepatutan dan berimpliaksi sanksi atas perbuatannya tersebut, dimana sanksi tersebut berasal dari masyarakat. Berbedaa halnya bila suatu aturan yang datang/lahir dari suatu kesepakatan-kesepakatan “hukum', atas perintah/ inisiatif kepala suku, adat atau pemerintah dan kesepakatan-kesepakatan "hukum" dilanggar/diabaikan/tidak dipatuhi/tidak dilaksanakan maka disebut pelanggaran.

\section{Kejahatan dan Pelanggaran dalam Perspektif Tujuan Hukum}

Berbagai literatur mencantumkan tujuan hukum yang pada umumnya menekankan satu tujuan pokok hukum, yaitu terciptanya keadilan bagi semua pihak. Kata adil secara umum mempunyai dimensi luas meliputi berbagai aspek kehidupan (idiologi, politik, ekonomi, sosial dan budaya). Namun pada perspektif yang berdimensi tujuan berhukum oleh beberapa pakar antara lain Gustav Raadbruch, mengemukakan tiga tingkatan tujuan hukum yakni; pertama, tercapai tujuan kepastian ada proses dan terwujud. Kedua, tercapainya suatu kemanfaatan bagi individu dan masyarakat. Ketiga, tercapai rasa adil bagi setiap individu dan Masyararakat.

Berbagai lieratur lain disebutkan, bahwa paling tidak hukum diciptakan untuk terwujudnya suatu ketertiban dan keadilan, suatu kepastian dan keadilan. Plato dan Aristoteles, mengartikan hukum itu adalah keadilan itu sendiri. Plato membagi keadilan ke dalam keadilaan distributif dan keadilan komutatif. Apa yang dikemukakan oleh Plato dalam perspetif luas meliputi keadilan semua aspek kehidupan sedang dalam perspektif hukumnya, boleh

\footnotetext{
${ }^{10}$ TV one, Obrolan Akhir Tahun tentang Catatan Kriminal dan Lalu Lintas Jalan Raya, Jakarta,
} 2018 
jadi keadilan komutatif adalah hukum yang harus dirasa bermanfaat semua orang, meskipun mengabaikan keadilan beberapa individu-individu yang ada. Sedangkan keadilan distributive merupakan keadilan yang berbanding lurus antara perbuatan dengan sanksi atas perbuatan.

\section{Kejahatan dan Pelanggaran dalam Perspektif Kaidah Hukum, Moral dan Kesopanan}

Pelanggaran atas kaidah-kaidah,aturan, dan norma akan berimplikasi sanksi atas perbuatan yang dilanggar sebagaimana dalam aturan hukum dan perundang-undangan yang ada berlaku saat ini "ius konstitutum". Olehnya bila suatu kaidah moral, kaidah kesopanan dan kaidah-kaidah sosial lainnya telah masuk atau telah terkualifikasi dalam perundang-undangan (hukum tertulis) dan atau telah terkualifikasi dalam adat dan kebiasaan, maka menjadi hukum adat dan hukum kebiasaan (hukum tidak tertulis).

Kata kejahatan adalah suatu perbuataan yang menyebabkan korban merasakan, sangat menyakitkan atau amat menyakitkan bagi korbannya baik fisik ataupun mental. Artinya secara hakiki, seharusnya pelaku diberi sanksi sepadan dengan perbuatan yang menyakitkan tersebut, berupa sanksi atau hukuman yang berat pula.

Kata pelanggaran adalah suatu perbuatan yang menyebabkan korbannya dapat merasakan dan amat menyakitkan tidak secara langsung. Hal ini dapat dicermati pada hukuman "denda atau kurungan" karena tidak memiliki suratsurat berkendaraan (SIM). Pada kasus pengendara motor yang menabrak pejalan kaki di pinggir jalan dan luka atau kehilangan nyawa, benar atau salah dan pelakunya tidak memakai SIM, maka pelaku penabrak dinyatakan dua kesalahan oleh negara (melukai dan tidak memakai SIM). Pengguna kendaraan yang tidak memiliki SIM kendaraan, maka telah dinyatakan bersalah (melanggar buka menjahati). Artinya karena boleh jadi nanti berakibat "sifat prediksi " menyakiti orang (tabrak atau serempet).

Berbeda halnya bila keduanya dalam keadaan benar tetapi terjadi tabrak/serempet dan penabrak memiliki SIM, maka hanya pada aspek pertanyaan "sengaja/niat? ataukah kelalaian?" mengakibatkan orang tidak salah (pejalan kaki) menjadi korban. Hal tersebut bila kendaraan dijadikan alat untuk menabrakkan atau sengaja menabrakkan, maka pidana "kejahatan". Adapun bila kelalaian (bila kendaraanya tidak sempurna atau pengemudinya tidak sempurna/tidak sadar), maka ada yang mekategorikan pelanggaran adapula kejahatan, menurut penulis adalah kejahatan dengan tanpa niat "seketika".

Adapun sanksi denda (uang atau kurungan/fisik) bagi pelanggar karena melanggar tidak memiliki perlengkapaan kendaraan atau surat, seperti yang disyaratkan dalam UU Lalu lintas Angkutan dan Jalan Raya (UU LLAJR). Artinya hakikat sanksi atau hukuman pada pelaku pelanggaran tidaklah berat "denda saja" kalaupun pelanggar kehendaki kurungan/fisik sebagai pilihannya, maka sanksi pelangggar tidaklah berat atau tidak lama. Karena kepemilikan isyarat (UULLAJR), adalah hukum pemerintah, bila tidak ditaati 
adalah pelanggaran sebagai satu hal dan sewaktu-waktu mencelakan orang atau diri sendiri "prediktibel". Alasan kepemilikan dan mengendarai dua hal di dalamnya. 1) konsekuensi pidana, 2). konsekuensi tata adminitrasi negara/hukum pajak, dipisahkan atau disatukan sifatnya kondisional.

\section{Perspektif Perkembangan Istilah}

Kata atau istilah kejahatan dan pelanggaran dalam perkembangannya mengalami penyusutan arti dan hakikat makna yang sama. Hal tersebut karena dilihat dalam kekuatan, jumlah atau berat ringannya sanksi yang diancamkan dalam beberapa perundang-undangan yang ada, karena beberapa perundangundangan yang ada pelaku kejahatan dan pelaku pelanggaran, secara kualitas dan kuantitas sanksi atau hukuman, kedua kata atau istilah tersebut tidak ada perbedaan tajam.

\section{PENUTUP}

Istilah kejahatan dan pelanggaran dalam persfektif pidana, mengalami kehilangan atau "terdistorsi" hakikat makna. Khusus kata kejahatan jarang digunakan dan lebih sering menggunakan istilah pelanggaran, yang konsekuensi sanksi yang ringan. Kecenderungan tersebut, diawali dari perspektif konstitusi, hukum tata negara, hukum pidana dan HAM.

Fenomena pemahaman dari istilah kejahatan dan pelanggaran lebih umum menggunakan kata"tindak pidana" saja. Ada beberapa pemicu hal tersebut yakni Rancangan Undang-Undang Hukum Pidana (RUU KUHP), aparat dan para praktisi hukum seringkali mengucapkan kata "tindak pidana", tanpa memberi penekanan adanya unsur delik kejahatan atau delik pelanggaran serta konsekuensinya masing-masing.

\section{DAFTAR PUSTAKA}

Apeldoorn, Inleiding tot de studie van het nederlandse recht, terj. Pengantar Ilmu Hukum, 1952.

Aswanto, Implementasi Penegakan Hukum dan HAM di Indonesia, Unhas, Makalah Seminar 2010.

Farid, Andi Zainal Abidin, Hukum Pidana I, Jakarta, Sinar Grafika, 2014. , Hukum Pidana, Remaja Rosda Karya, 2007.

Hiariej, Eddy O.S, Prinsip-Prinsip Hukum Pidana, Cahaya Atma Pustaka, Yokyakarta, 2014.

Peter, Mahmud Marzuki, Penelitian Hukum, Cetakan kelima, Kencana Prenada Media Group, Jakarta, 2009.

Prajogo, Soesilo, Kamus Hukum Internasional dan Indonesia, Wacana Intelektual, Jakarta, 2007.

Rahardjo, Satipto, Ilmu Hukum, Citra Aditya Bakti, Bandung, 2006. 
Soesilo R, KUHP Beserta Komentar-Komentar Pasal Demi Pasal, Penerbit Politea, Bogor, 1990.

Soekanto, Soerjono, Pengantar Penelitian Hukum, UI Press, Jakarta, 2007.

Supriyadi, Penetapan Tindak Pidana Sebagai Kejahatan dan Pelanggaran dalam Undang-Undang Pidana Khusus, Jurnal Mimbar Hukum UGM, Volume, 27 no.03 oktober 2015.

TV One, Refleksi Kemandirian Hukum dan Kekuasaan Dalam Negara Demokrasi, Diskusi Hukum, Jakarta Desember, 2017.

TV One, Obrolan Akhir Tahun, Catatan Kriminal dan Lalu Lintas Jalan Raya, Jakarta, Desember, 2018.

Eddy O.S. Hiariej, Prinsip-Prinsip Hukum Pidana (Cahaya Atma Pustaka, Yokyakarta, 2014). h, 101-102. 